\title{
Treating Arithmetical Text Problem Solving in a Child with Intellectual Disability: An Observative Study
}

\author{
Margherita Orsolini*, Chiara Toma and Barbara De Nigris
}

Dipartimento di Psicologia dei Processi di Sviluppo e Socializzazione, Università “La Sapienza”, Roma, Italy

\begin{abstract}
In this single case study we analyze the treatment focused on arithmetical text problems with a multiplicative structure that was offered to Lu., a 7.8-years-old child who had been diagnosed with mild mental retardation and a genetic anomaly (cariotype $47 \mathrm{XYY}$ ) associated with learning disabilities and language delay. Our main aim is to analyze the longitudinal learning profile of our target child in order to identify both the major sources of difficulties interfering with effective learning and the internal cognitive constructions linked to his acquisitions. We deploy qualitative observations tracking the longitudinal changes in the procedures that Lu. applied to the tasks and in adult-child interactive talk.

We identified three types of cognitive difficulties interfering with effective learning of solving arithmetical text problems: sensitivity to interference effects in verbal working memory, difficulties with complex coordination of sequential actions, slow automatization. The longitudinal analysis of the adult-child interactive talk showed that the child's talk changed from being almost exclusively focused on giving simple answers, to producing descriptions and anticipation of computations or procedures. It is likely that this use of language provided $\mathrm{Lu}$. with an abstract representational format that triggered an internal reorganization and conceptualisation of the acquired problem-solving procedures.
\end{abstract}

In this study we maintain that treatments for children with cognitive deficits should be devised answering three crucial questions. The first is how, in each specific domain (e.g. language, numerical cognition) children can be helped to represent and memorise basic input data and to organize procedures. Asking such question leads us to assess [1], treat or compensate the processing (e.g. selective attention) and the output mechanisms (e.g. inhibitory control) enabling the individual to encode visual, auditory, tactile information and to build procedures exploiting such information.

The second question, rooted to a developmental constructivist framework [2], is how children can be helped to build internal representational changes allowing them to expand functional uses of their knowledge. A change from implicit, sometimes holistic, procedurally encapsulated representations to analyzed, explicit representations may enhance generalizations from one micro-domain to another, allow children to access knowledge in a more flexible way, and create strategies to cope with new unfamiliar tasks. For instance, re-describing the perceptual image of a zebra as a "striped animal" [2] allows the cognitive system to understand the analogy between the zebra and the "zebra crossing" sign. Karmiloff-Smith [2] hypothesizes that re-describing in different representational formats the information acquired in a specific domain is an intraindividual, endogenous process. The use of language and other symbolic codes within the rehabilitation context might provide, however, a crucial environmental factor triggering such endogenous process in the child. Describing actions, anticipating their goals, explaining their outcomes, spatially and visually representing linguistic

*Address correspondence to this author at the Dipartimento di Psicologia dei Processi di Sviluppo e Socializzazione, Università "La Sapienza", Via dei Marsi 78, 00185 Roma, Italy; Tel: (+39) 06 49917920; Fax: (+39) 06 4991 7652; E-mail: margherita.orsolini@uniroma1.it information or arithmetic procedures can provide multiply encoded knowledge. Such multiple encoding can promote the conceptualization of the relationships among internal components of the procedures that the child might have mastered through modelling or other types of teaching practices.

The third question is how to address the children's emotional problems that are associated to their cognitive deficits. Such question may be interpreted in a rather decontextualized way, considering the child's attachment bonds with his parents, and how these bonds contributed to the child's emotional development. We think that such more general approach to emotions can be useful in some cases of children with cognitive deficits and obviously requires a close collaboration between parents, clinical psychologists or psychotherapists on one hand and cognitive rehabilitators on the other. More specific questions, however, should be addressed by cognitive rehabilitators. Which emotions are related to certain strategies the child has built to compensate his deficit? In a complex system [3] the alterations of one part of it are likely to be reflected in a change in behaviour of the other parts. For instance, a child with cognitive delays might overuse previously acquired routines as a strategy to decrease the fear of failure in difficult tasks. He may also prefer giving chance answers rather than saying "I do not know". The diagnosis of mental retardation may induce rehabilitators to interpret the child's incorrect answers in terms of "weak reasoning abilities". This interpretation, in turn, makes the rehabilitator deploy suggestive questions or direct modelling in order to overcome the child apparent lack of learning progress. Detecting the emotional aspects of the child's wrong answers and the emotional response and attributions that these answers elicit in the rehabilitator is likely to result in adult-child interaction patterns that can enhance the child's sense of self-efficacy and agentivity [4]. 
The three questions overviewed above inspired one specific treatment that was part of the long-term rehabilitation of a child who had been diagnosed with "mild mental retardation". The treatment addressed the child's ability to solve arithmetical text problems.

\section{THE COMPLEXITY OF ARITHMETICAL TEXT PROBLEM SOLVING}

Arithmetical text problem solving is a complex domain combining knowledge and procedures from numerical cognition and language. Similarly to other types of text comprehension, readers can comprehend a word problem if they build a cohesive mental representation [5] that is developed in an incremental way by mapping on incoming linguistic information. According to van Dijk and Kintsch [6] this representation consists of a situational model, that is "the cognitive representation of the events, actions, people and in general the situation that a text is about". To comprehend a text, each sentence needs to be processed and integrated [7] within the situational model by establishing conceptual links between referents. To build a cohesive mental representation of arithmetical text problems readers have to link referents in domain specific ways, through relationships between numerical quantities.

Here is a very simple problem with a multiplicative structure: "Julia has 3 bags; in each bag there are 2 wallets. How many wallets does Julia have?" In this problem children have to represent a one-to-many relationship between elements of the set A (i.e. bags) and elements of the set B (i.e. wallets) and infer that set $B$ increases in quantity as a consequence of this relationship. The conceptual relationship linking bags and wallets in this problem might be represented in a less or more abstract way by children. They could mentally visualize three transparent bags, each with two coloured wallets inside; a more abstract schema could be constructed, in which the word "bag" is repeated three times and each one is linked to the Arabic symbol "2". Alternatively, children might recognize that the current problem has a multiplicative schema [8-10] that has been built through solving other similar problems. Such schema allows children to categorize the new text and select arithmetical procedures (e.g. repeated adding or multiplying) to solve it.

It has been hypothesized that schemata underlying problem solving consist of amodal propositions that operate on sets [8]; but how children may develop such abstract propositional representations is unclear. We assume that the conceptual relationships used by children to represent a text problem are initially highly situated, as suggested by studies such as Hudson's [11]. Hudson showed children of different age groups a picture of five birds and four worms. Asking "Suppose the birds all race over and each one tries to get a worm. Will every bird get a worm? How many birds won't get a worm?". Even nursery school children could solve the problem when such question was asked. On the contrary, asking "How many more birds than worms are there?" lead to a much poorer performance even in first grade children. Thus a text problem inducing children to build a situationmotivated relationship could be more successfully represented compared to a problem in which conceptual relationships had to be represented in a more abstract way.
How children move from highly situated to more abstract conceptual relationships is an open question. It can hypothesized that children are first helped by adults to deploy a computation procedure and then learn to analyze in a more explicit way the relationship (e.g. a one-to-many correspondence between two sets) involved in such procedure.

In addition to representing conceptual relationships, solving text problems involves the ability to focus attention on numerals, key words (as "in each", "how many"), text questions. Processing several pieces of information coordinatedly deeply involves working memory. Several studies have provided evidence that arithmetical text problem solving is specifically delayed in children who have typical reasoning abilities but impaired verbal working memory or attention skills [12-16]. Also finding that variables such as word length, number of sentences or number of verbs affect children's effective problem solving [17] confirms the role of verbal working memory in such domain.

Impaired executive functions, including not only deficits of working memory, but also difficulties with attentional inhibitory control, low flexibility, little resistance to interference effects, difficulties with process updating, is also likely to undermine children's performance with arithmetical text problem-solving $[18,19]$. Integrating the semantic content of sequential sentences, selecting a procedure from a range of possible procedures flexibly, monitoring one subgoal at a time while others are inhibited, are all cognitive processes that rely on executive functions. Impairments of executive functions are involved not only in specific learning disabilities, but they are also a central neuropsychological characteristic of several genetic syndromes associated with intellectual disability, including children with Fragile X $[20,21]$ or Down syndrome $[22,23]$. The deep difficulties with problem-solving and the preservative thought often observed in people with intellectual disability are also likely to have been generated by impairments of executive functions [24].

Treating arithmetical text problem-solving in a child with intellectual disability thus challenges the rehabilitator's ability to enhance the acquisition of complex procedures in the context of impaired executive functions.

\section{AIMS OF THE STUDY}

In this single case study we analyze a treatment focused on arithmetical text problems with a multiplicative structure. We are not aimed at assessing the efficacy of our treatment in terms of final learning outcomes in the child. This is indeed an important goal for rehabilitation studies but we think that such experimental approach can be usefully complemented by observative studies that analyze the cognitive processes activated within the complexity of a treatment. Such analyses can provide information for a fine-grained planning of the treatment, contributing to a detailed specification of productive adult-child interactive strategies whose efficacy can be eventually assessed with experimental methods.

Our main aim is to analyze the longitudinal learning profile of our target child in order to identify both the major sources of difficulties that interfered with effective learning and the internal cognitive constructions associated with his acquisitions. More specifically, we explore whether at some point during the treatment our child showed a change from 
implicit to more explicit representations. In other words, will our target child show some conceptualisation of the acquired procedures? We are not asking whether a child with intellectual disability can learn to deploy metacognitive analyses that have been explicitly taught by a teacher (see, for instance [25]). We are asking instead whether an internal construction of the child, leading from implicit to a more explicit representation of procedural knowledge [2], has emerged at some stage during our longitudinal treatment. To investigate this issue we deploy qualitative observations tracking the longitudinal changes in the procedures that our target child applied to the tasks. We also explore whether the discourse practices in which the child has been involved show a child's emerging capability of using language to describe and analyze the acquired procedures.

\section{CASE REPORT}

$\mathrm{Lu}$. was born preterm at the 33rd week in a working class family. Neurological controls in the first year of life did not detect abnormalities. A language and motor delay was assessed when the child was seventeen months old. Lu. received speech therapy for about one year when he was 4 years old. At 7 years of age, at the end of grade 1, he showed mild difficulties in reading and writing, and severe difficulties with arithmetic. Lu. was thus referred to the neuropsychiatric developmental service of the "Bambino Gesù" Hospital in Rome, where he was diagnosed with mild mental retardation. It was also underlined that $\mathrm{Lu}$. had a very low self-esteem and was very concerned with external evaluations. A genetic analysis revealed that $\mathrm{Lu}$. had a rare genetic anomaly (cariotype $47 \mathrm{XYY}$ ) associated to learning disabilities and language delay. When Lu. arrived at our University laboratory he was 7.8 years old. Our assessment with the Wisc-R [26] confirmed that the IQ was below norms (Verbal $\mathrm{IQ}=71$; Performance IQ=75).

We summarized in Table $\mathbf{1}$ the main psychometrics findings of our initial cognitive assessment. Lu. showed a remarkable delay in expressive and receptive vocabulary, visual planning, visuo-constructive skills, numerical knowledge. He lacked strategies to encode and retrieve verbal information from long term memory. His areas of strength were verbal short term memory, selective attention, and reasoning about social situations.

Let us describe in a more dynamic way the cognitive processes that we could observe in our video-recordings, when $\mathrm{Lu}$. addressed our tests and initial cognitive rehabilitation tasks. Lu. was very thoughtful in several tests but highly impulsive in Arithmetic (subtest from the Wisc-R) in which he tended to give chance answers when he had to manipulate numbers through some computation. He told us that he hated numbers. Organizing several pieces of information in a whole or in a sequence was extremely difficult for him. For instance, if you proposed a riddle saying "It is a part of the body. We use it to speak, eat and yawn", he answered that it was the hands, because you need hands to eat. Tasks that required controlling over the execution of more than one instruction or inhibiting a highly activated answer or routinized behaviour were also very difficult. All these observations suggested impaired executive functions. An executive function testing was made available in a follow-up assessment one year after the treatment. The impairment of executive functions, initially hypothesized from our observations, was indeed confirmed by such tests.

Table 1. Initial Assessment of Lu. at 7.8 Years of Age (January-February 2005, One Year Before Treating Arithmetical Text Problem Solving)

\begin{tabular}{|c|c|c|}
\hline Abilities & Tests & Performance \\
\hline Selective Attention & Search for two symbols [31] & In norm \\
\hline Verbal Long Term Memory & $\begin{array}{l}\text { Recall of stories, named objects, pairs of words } \\
\text { (from TOMAL [32]) }\end{array}$ & Below norms (Mean zeta score in the three subtests $=-1.7$ ) \\
\hline Visual Long Term Memory & Memory of abstract patterns (from TOMAL [32]) & In norm \\
\hline Visual-Spatial abilities & Developmental Test of Visual Perception [33] & In norm (Mean percentile in six subtests $=30$ ) \\
\hline Visual-constructive skills & Block Design (from the WISC-R [26]) & Below norms (Weighted score at the WISC-R=5) \\
\hline Language -Expressive Lexicon & Picture naming [34] & Below norms for low frequency words (zeta score $=-6$ ) \\
\hline Language -Receptive Lexicon & Peabody Picture Vocabulary Test [35] & Below norms (zeta score $=-1$ ) \\
\hline Reading - Text comprehension & Reading Acquisition Test [37] & In norm \\
\hline $\begin{array}{l}\text { Arithmetic (The test devised for } \\
\text { children at the end of grade } 1 \\
\text { was administered after six } \\
\text { months of rehabilitation when } \\
\text { Lu. was } 8.6 \text { years old and en- } \\
\text { rolled in grade } 3 \text { ) }\end{array}$ & Test AC MT [38] & $\begin{array}{l}\text { In norm for children at the end of grade } 1 \\
\text { Written computations }\left(20^{\text {th }} \text { percentile }\right) \\
\text { Knowledge of numbers }\left(30^{\text {th }} \text { percentile }\right) \\
\text { Errors }\left(95^{\text {th }} \text { percentile }\right) \\
\text { Speed }\left(40^{\text {th }} \text { percentile }\right)\end{array}$ \\
\hline
\end{tabular}


Table 2. Aims and Timetable of Lu.'s Treatment

\begin{tabular}{|c|c|c|}
\hline Aims & When \& How Long & Contents \\
\hline $\begin{array}{l}\text { Enhancing language de- } \\
\text { velopment and use }\end{array}$ & $\begin{array}{l}\text { The first year, for } 9 \\
\text { months ( } 45 \text { minutes } \\
\text { each session) }\end{array}$ & $\begin{array}{l}\text { Activities enhancing conceptualization, representation of semantic differences and similiarities, } \\
\text { lexicon acquisition, text comprehension, integrating the semantic content of different sentences to } \\
\text { build a mental model, narrative discourse. }\end{array}$ \\
\hline $\begin{array}{l}\text { Building basic numerical } \\
\text { abilities }\end{array}$ & $\begin{array}{l}\text { The first year for } 5 \\
\text { months ( } 30 \text { minutes } \\
\text { each session) }\end{array}$ & $\begin{array}{l}\text { Enhancing the representation of the mental numbers line, matching numerical quantities with Ara- } \\
\text { bic numbers, ordering numbers, retrieving simple addition and subtraction facts. }\end{array}$ \\
\hline \multirow[t]{2}{*}{$\begin{array}{l}\text { Learning to solve arith- } \\
\text { metical text problems } \\
\text { with multiplicative struc- } \\
\text { ture }\end{array}$} & $\begin{array}{l}\text { The second year for } 4 \\
\text { weeks ( } 20 \text { minutes } \\
\text { each session) }\end{array}$ & $\begin{array}{l}\text { Phase } 1 \text { Intervention } \\
\text { Representing the multiplicand-multiplier relation through semantically motivated relationships } \\
\text { (mainly body part-object relationships, such as ears-earrings). } \\
\text { Text problems were illustrated. }\end{array}$ \\
\hline & $\begin{array}{l}\text { The second year for } \\
12 \text { weeks }(20 \text { minutes } \\
\text { each session) }\end{array}$ & $\begin{array}{l}\text { Phase } 3 \text { Intervention } \\
\text { Consolidating the representation and the analysis of the multiplicand-multiplier relation. Texts } \\
\text { were never pictured and involved arbitrary relations (e.g. candies and number of days in a week). } \\
\text { The large majority of texts provided numerical information in the order that was easier for Lu. (i.e. } \\
\text { "set A first"). Text problems that mentioned set B first or required two steps (a sequence of two } \\
\text { multiplicative relationships and a final addition) were presented very rarely. }\end{array}$ \\
\hline
\end{tabular}

\section{METHOD}

\section{Overview of Lu.'s Rehabilitation}

Lu. was treated in our laboratory in weekly sessions of one hour and a half in the first year and two hours in the following years. In each session there was a regular sequence of activities that we tended to follow: first, warm-up with conversation or sharing narratives; then one activity that would be cognitively challenging and required some explanatory thinking; this was followed by a more relaxing activity practicing memory, attention, vocabulary, text comprehension, spatial abilities through some kind of drills. The final part of the session was devoted to either pretend play or other games with the rehabilitator.

As shown in Table 2, in the first year of cognitive rehabilitation we had two main goals: enhancing language development and use; building basic numerical abilities. Some of the first year's activities were aimed at developing verbal processing skills that are also involved in text comprehension and arithmetical text problem solving. Such activities required $\mathrm{Lu}$. to integrate different items of verbal information to build a mental model.

We treated arithmetical text problem solving in the second year of cognitive rehabilitation after Lu. showed arithmetical abilities typical of end of grade 1 children and was able to solve simple problems with additions. The time devoted to arithmetical text problem solving was about twenty minutes each week. The treatment was divided into three periods each characterized by specific learning objectives (see Table 2). The second and third phases were separated by an interval of two months of vacation.

Turning to the questions phrased in the introduction section, the goal of facilitating the representation of input data in the specific arithmetical text problems domain was mostly addressed through compensative strategies: structuring the types of text and the adult-child verbal interaction in a way that could mitigate the difficulties in organizing actions and procedures that $\mathrm{Lu}$. had shown in initial rehabilitation tasks. First, representing the multiplicand-multiplier relation was initially highly semantically motivated and anchored to body part-object (e.g. ears-earrings) and to container-content associations. We hypothesized that semantic plausibility could be a major facilitation to transform the text linguistic information into a visual-spatial representation of the multipliermultiplicand relation.

We attempted to facilitate the action organization using two types of tool. First, we introduced a sharp distinction between understanding and representing the relation between the text numerical quantities on one hand, and selecting a computation in order to answer the text question on the other hand. Second, within the verbal interaction with the rehabilitator the child was provided with directions about the actions to be carried on. These directions were progressively reduced as the child was acquiring basic procedures [27]. Verbal interaction was also used by the rehabilitator as a sort of shared interactive working memory in which what was going on was described and cues to shift to a new phase of the activity were provided. The adult attempted to follow a few 
general rules in the structuring of the adult-child verbal interaction. First, the adult was to take into account two apparently contradictory aims: leading the child to solve the problem and enhancing the child's control over the activity. For instance, the adult would give direct suggestions when the child did not know how to represent the relationship between numerical quantities in the text problem. At the same time, after giving the child some cues for the procedure to adopt, the adult would also ask something like "What do you think we should do next?" The second rule regarded "errors": the adult's talk should encourage the child's self-correction. The adult should produce repetitions, rephrasing, requests of selfrepair in order to enable the child's self-correction and attention focusing. The third rule dealt with the adult not only being interested in the child's correct performance but also in the child "thinking out loud". Requests of describing actions and explaining solutions would always be asked whenever the child applied a correct procedure.

Focusing on the second question -enhancing the child's change from implicit to more explicit representations- our explorative tool was asking the child both to represent graphically the text numerical quantities and their relation, and stimulating the use of language to anticipate the actions that were to be carried on and explain the procedures that had lead to correct solutions. We assumed that graphic symbols and both regulative and explanatory uses of language would provide the child with multiple levels of encoding for the same knowledge and could trigger an internal conceptual redescription [2].

The issue of taking into account the child's emotions was mainly addressed through monitoring adult-child interaction using video-recordings. Let us describe one example of the emotional thinking that video-recording revealed. In a preparatory phase Lu. read for the first time a problem with a multiplicative structure, gave a quick answer consisting in adding everything and did not express any sign of uncertainty or trouble. When the adult elicited a self-correction, Lu. covered his eyes with one arm and yawned. He also spoke at a very low volume and in a childish way. We hypothesized that Lu.'s impulsive answer (i.e. adding everything) might also serve an emotional function: he was trying to contrast the emotional experience of uncertainty by addressing the new task with an old procedure that he knew in the past had led him to success. The adult's interactive strategies appeared inadequate in this preparatory phase. Probably as a reaction to Lu.'s sore feeling the rehabilitator felt rather anxious and tried to drive Lu. as much as possible towards the solution. Such experience was conceptualized by the adult in terms of need of talking about uncertainty and difficult thinking. On one hand, Lu. was involved in a conversation on "what we could do when things are very difficult". The rehabilitator, on the other hand, reflected on the fact that helping a child with intellectual disability to conceptualise multiplicative relations also required adult's "difficult thinking" and time to construct it.

\section{Data Collection and Statistical Analyses}

Each treatment session was video recorded through a fixed camera that was turned on as soon as the child entered the treatment room and turned off at the end. We used video recordings -throughout Lu.'s rehabilitation- to monitor the emotional aspects of adult-child interaction and to evaluate the changes we might need to introduce in the planned treatment activities.

In this study we specifically analysed the 23 video recordings in which $\mathrm{Lu}$. was treated for arithmetical text problem solving (in two sessions the video recording got spoiled). We transcribed the verbal interaction occurring between $\mathrm{Lu}$. and the rehabilitator for each problem-solving session. Transcriptions were used with three objectives: a) describing in a qualitative way the Lu.'s longitudinal learning profile in terms of problem-solving strategies and major sources of difficulties; b) analysing Lu.'s correct and incorrect performance (see Fig. (1) and the post-test in the results section); c) identifying the longitudinal changes in rehabilitator-child interactive talk (see Figs. $(2,3)$ in the results section).

The data analysis of categories of adult-child interactive talk (see the following section) involves the use of Chi Square. Standardized residuals -that will be reported when statistically significant chi-square values will be found- allowed us to identify the categories that made a significant contribution to the chi square value. Following Haberman's guideline, it was inferred that where the standardized residual for a category was greater than 2, that category was strongly contributing to the significant chi square value [28].

\section{Analyzing the Rehabilitator-Child Interactive Talk}

For each intervention phase (Table 2) we selected the first seven text problems presented to $\mathrm{Lu}$. and coded the adult-child verbal interaction occurred. We selected the first seven problems because the three phases had a different duration. Had we selected the last seven problems, the child's performance in phase 3 would have reflected a much longer period of practice compared to the second or first phase. The 631 turns at talk included in the 21 adult-child interactions were labelled according to the category system described as follows. The two coders categorized the whole set of transcriptions independently (all 631 turns were coded and checked for agreement).

Our unit of analysis is the talk included in each turn. We did not categorize the first turns in which the text problems were read. Talk turns consisting only of discourse markers (e.g."well...", "so...") or focused on a secondary activity (e.g. "can I have that pen?") were not categorized either.

Table 3 lists the adult's talk categories that were constructed taking into account two dimensions. The first is semantic contingency, distinguishing talk that continues the semantic focus of the child's previous turn from talk that changes the semantic focus of the child's previous turn. The second dimension encodes different types of cognitive support provided by the adult to the child's activity. First, there is adult talk making suggestions or asking questions in order to drive the child to perform particular physical or mental actions (e.g. "you could write that down"). This type of talk may be used to help the child in representing the text situation model and may suggest computation procedures or actions enabling the child to check the correctness of what has been said (e.g. "If you are not sure of what you should do, read the problem text once more"). Second, there is talk enhancing the child's control of attention. In this type of turns the rehabilitator does not make specific suggestions but helps 
Table 3. Categories for the Adult's Talk

\begin{tabular}{|c|c|c|c|c|c|c|c|}
\hline & \multicolumn{6}{|c|}{ Cognitive Support } & \multirow{3}{*}{$\begin{array}{l}\text { Emotional Support } \\
\\
\text { Talk that Provides } \\
\text { Emotional Support } \\
\text { Through Positive } \\
\text { Evaluations and } \\
\text { Encouragements }\end{array}$} \\
\hline & \multicolumn{2}{|c|}{$\begin{array}{c}\text { Suggestions to Perform Par- } \\
\text { ticular Physical or Mental } \\
\text { Actions }\end{array}$} & \multicolumn{2}{|c|}{$\begin{array}{l}\text { Questions, Rephrasings, Repeti- } \\
\text { tions Enabling the Child to } \\
\text { Maintain the Attention on the } \\
\text { Activity, or to Shift the Attention } \\
\text { on a New Phase of the Activity }\end{array}$} & \multicolumn{2}{|c|}{$\begin{array}{c}\text { Building Explanations and } \\
\text { Re-Descriptions of the Child's Ac- } \\
\text { tions }\end{array}$} & \\
\hline & $\begin{array}{c}\text { Semantic } \\
\text { Contingency }\end{array}$ & $\begin{array}{l}\text { No Semantic } \\
\text { Contingency }\end{array}$ & $\begin{array}{c}\text { Semantic } \\
\text { Contingency }\end{array}$ & $\begin{array}{l}\text { No Semantic } \\
\text { Contingency }\end{array}$ & $\begin{array}{c}\text { Semantic } \\
\text { Contingency }\end{array}$ & $\begin{array}{l}\text { No Semantic } \\
\text { Contingency }\end{array}$ & \\
\hline $\begin{array}{l}\text { Examples } \\
\text { from trascrip- } \\
\text { tions }\end{array}$ & $\begin{array}{l}\text { (Lu. antici- } \\
\text { pated that the } \\
\text { right compu- } \\
\text { tation is four } \\
\text { times two and } \\
\text { said he did not } \\
\text { know the } \\
\text { result) } \\
\text { Rehabilitator: } \\
\text { "Let's do it } \\
\text { together, I'll } \\
\text { lend you one } \\
\text { hand (show- } \\
\text { ing four fin- } \\
\text { gers) and you } \\
\text { put the other } \\
\text { one" }\end{array}$ & $\begin{array}{l}\text { (Lu. antici- } \\
\text { pated the } \\
\text { right compu- } \\
\text { tation and } \\
\text { executed it } \\
\text { correctly } \\
\text { through a } \\
\text { repeated } \\
\text { addition) } \\
\text { Rehabilitator: } \\
\text { "Twelve, } \\
\text { right. Is there } \\
\text { another way } \\
\text { to solve the } \\
\text { problem? } \\
\text { The way you } \\
\text { found is very } \\
\text { good but let's } \\
\text { try to think if } \\
\text { there are } \\
\text { other possi- } \\
\text { ble ways" }\end{array}$ & $\begin{array}{l}\text { (The text } \\
\text { problem says } \\
\text { that Sara has a } \\
\text { hole in all the } \\
\text { tyres of her } \\
\text { car. The pic- } \\
\text { ture shows the } \\
\text { front of a car } \\
\text { and only two } \\
\text { tyres are visi- } \\
\text { ble.) } \\
\text { Lu. : "Two } \\
\text { tyres have } \\
\text { holes" } \\
\text { Rehabilitator: } \\
\text { "Two tyres?" } \\
\text { Lu.: "Yes } \\
\text { because } \\
\text { somebody } \\
\text { made a hole in } \\
\text { two tyres" } \\
\text { Rehabilitator: } \\
\text { "How many } \\
\text { tyres does a } \\
\text { car have?" } \\
\text { Lu.: "Four, so } \\
\text { I have to draw } \\
\text { four" ((start- } \\
\text { ing to draw a } \\
\text { schema)) }\end{array}$ & $\begin{array}{l}\text { (Lu. has just } \\
\text { finished draw- } \\
\text { ing a schema.) } \\
\text { Rehabilitator: } \\
\text { "What does } \\
\text { the problem } \\
\text { want to } \\
\text { know?" } \\
\text { Lu.: "How } \\
\text { much does } \\
\text { each lamp } \\
\text { cost?" }\end{array}$ & $\begin{array}{l}\text { Lu. reads the } \\
\text { text "Mister } \\
\text { Brown puts } 4 \\
\text { litres of petrol } \\
\text { in the car. Each } \\
\text { litre costs } 2 \\
\text { Euro. How } \\
\text { much does he } \\
\text { spend in all?" } \\
\text { and after a } \\
\text { pause says "two } \\
\text { is repeated four } \\
\text { times" and then } \\
\text { "It costs } 8 \text { euro" } \\
\text { Rehabilitator: } \\
\text { "Very good! } \\
\text { What did you } \\
\text { do to solve it?" } \\
\text { Lu."I repeated } 2 \\
\text { four times. } 2 \\
\text { plus } 2 \text { plus } 2 \\
\text { plus } 2 \text { ((adding } \\
\text { two fingers } \\
\text { each time)) }\end{array}$ & $\begin{array}{l}\text { (Lu. has drawn } \\
\text { three lamps and } \\
\text { anticipates that } \\
\text { the schema } \\
\text { should be com- } \\
\text { pleted writing } 10 . \\
\text { The rehabilitator } \\
\text { suggests reading } \\
\text { the text again.) } \\
\text { Lu.: "Each lamp } \\
\text { costs 10 Euro" } \\
\text { ((reading)) } \\
\text { Rehabilitator: } \\
\text { "Uhm, each. } \\
\text { Look, it is like } \\
\text { the soldiers' } \\
\text { problem. Each } \\
\text { soldier has three } \\
\text { swords. Here it's } \\
\text {-each lamp..." } \\
\text { Lu.: "Then each } \\
\text { lamp costs } 10 \\
\text { Euro" }\end{array}$ & $\begin{array}{l}\text { (Lu. is completing a } \\
\text { schema and making a } \\
\text { computation at the } \\
\text { same time.) } \\
\text { Lu.: "Three here plus } \\
\text { three here" ((writing } \\
\text { down } 3 \text { under the first } \\
\text { two rectangles in his } \\
\text { schema)) "and makes } \\
\text { six". } \\
\text { Rehabilitator: "Yes" } \\
\text { Lu.: "Plus three here" } \\
\text { ((writing down 3)) "and } \\
\text { makes nine". } \\
\text { Rehabilitator: "Yes" } \\
\text { Lu.: "Plus three here" } \\
\text { ((writing down 3)) "and } \\
\text { makes eleven, twelve". } \\
\text { Rehabilitator: "Twelve, } \\
\text { very good!" }\end{array}$ \\
\hline Explanation & $\begin{array}{l}\text { The rehabili- } \\
\text { tator elabo- } \\
\text { rates on Lu.'s } \\
\text { focus (i.e. } \\
\text { how to com- } \\
\text { pute) and } \\
\text { starts a proce- } \\
\text { dure }\end{array}$ & $\begin{array}{l}\text { The rehabili- } \\
\text { tator changes } \\
\text { Lu.'s focus } \\
\text { from seeking } \\
\text { the result to } \\
\text { seeking a } \\
\text { different } \\
\text { procedure. }\end{array}$ & $\begin{array}{l}\text { The rehabilita- } \\
\text { tor asks ques- } \\
\text { tions enabling } \\
\text { Lu. to self } \\
\text { repair his } \\
\text { previous } \\
\text { statement. }\end{array}$ & $\begin{array}{l}\text { The rehabilita- } \\
\text { tor does not } \\
\text { pick up Lu.'s } \\
\text { action (the } \\
\text { drawn } \\
\text { schema) and } \\
\text { asks one ques- } \\
\text { tion enabling } \\
\text { Lu. to shift to } \\
\text { a new phase of } \\
\text { the activity. }\end{array}$ & $\begin{array}{l}\text { The rehabilita- } \\
\text { tor acknowl- } \\
\text { edges that Lu. } \\
\text { solved the prob- } \\
\text { lem and asks to } \\
\text { explain how he } \\
\text { reached the } \\
\text { solution. }\end{array}$ & $\begin{array}{l}\text { Lu.'s focus was } \\
\text { "how to complete } \\
\text { the schema". The } \\
\text { rehabilitator } \\
\text { changes the focus } \\
\text { pointing to a } \\
\text { structural simi- } \\
\text { larity between } \\
\text { the current and a } \\
\text { previously ad- } \\
\text { dressed text } \\
\text { problem. }\end{array}$ & $\begin{array}{l}\text { Each of the rehabilita- } \\
\text { tor's turns in this se- } \\
\text { quence serves the main } \\
\text { purpose of providing } \\
\text { emotional support. }\end{array}$ \\
\hline
\end{tabular}

the child to maintain attention on what he is doing or to shift attention to a new phase of the activity. Talk may consist of questions eliciting the child's self-repairs or utterances rephrasing and repeating the child's previous talk (see the example in Table 3 above). Third, there is talk focused on building explanations and re-descriptions of the child's actions: the rehabilitator may focus on the differences between ways of computing, or point to the similarities between different text problems, or start one explanation that has to be continued by the child. Talk providing only emotional evaluations (e.g. "You were very good!") is coded with no analysis of semantic contingency.
Table 4 lists the child talk categories that were constructed by taking into account the degree of cognitive control shown by the child during the activity of solving text problems. The lowest cognitive control shows in simple answers to the rehabilitator's questions or talk through which the child elicits some help from the adult, or continues utterances started by the adult. An intermediate degree of cognitive control appears in talk showing the child's emerging ability either to control actions and claims in terms of correctness, or to regulate action execution through external language [29]. We included in the former, the child's talk asking the adult to confirm the correctness of self-initiated actions or previous claims, and -in the latter- talk focused on describing and verbally reporting the actions that the child is 
Table 4. Categories for the Child's Talk

\begin{tabular}{|c|c|c|c|c|c|c|c|}
\hline & \multicolumn{2}{|c|}{ Low Cognitive Control } & \multicolumn{2}{|c|}{ Intermediate Cognitive Control } & \multicolumn{2}{|c|}{ High Cognitive Control } & \multirow[b]{2}{*}{$\begin{array}{c}\text { Talk that Only } \\
\text { Expresses Emo- } \\
\text { tional Involve- } \\
\text { ment }\end{array}$} \\
\hline & $\begin{array}{l}\text { Simple An- } \\
\quad \text { swers }\end{array}$ & $\begin{array}{l}\text { Eliciting Some } \\
\text { Help or Continu- } \\
\text { ing Utterances that } \\
\text { have been Started } \\
\text { by the Adult }\end{array}$ & $\begin{array}{c}\text { Asking the Adult to } \\
\text { Confirm the Cor- } \\
\text { rectness of the } \\
\text { Child's Actions or } \\
\text { of Previous State- } \\
\text { ments }\end{array}$ & $\begin{array}{l}\text { Describing } \\
\text { Ongoing } \\
\text { Actions }\end{array}$ & $\begin{array}{l}\text { Anticipating } \\
\text { Procedures or } \\
\text { Computations }\end{array}$ & $\begin{array}{c}\text { Evaluating } \\
\text { and/or Ex- } \\
\text { plaining Ac- } \\
\text { tions or } \\
\text { Claims }\end{array}$ & \\
\hline $\begin{array}{l}\text { Examples } \\
\text { from the tran- } \\
\text { scriptions }\end{array}$ & $\begin{array}{l}\text { (Lu. does not } \\
\text { know how to } \\
\text { proceed after } \\
\text { reading a text } \\
\text { problem. The } \\
\text { rehabilitator } \\
\text { suggests } \\
\text { "Look at the } \\
\text { problem, } \\
\text { what it says } \\
\text { there?" } \\
\text { Lu. "three } \\
\text { bicycles" }\end{array}$ & $\begin{array}{l}\text { (Lu. is drawing a } \\
\text { schema) } \\
\text { Lu.: "How should I } \\
\text { draw the little } \\
\text { mosquitoes?" }\end{array}$ & $\begin{array}{l}\text { (Lu. wrongly in- } \\
\text { ferred that three } \\
\text { lamps cost ten euro } \\
\text { in all. The rehabili- } \\
\text { tator says "One } \\
\text { lamp costs ten euro" } \\
\text { Lu.: Ah, one?" }\end{array}$ & $\begin{array}{l}\text { (Lu. has just } \\
\text { read the text } \\
\text { problem. He } \\
\text { starts to } \\
\text { draw a } \\
\text { schema) } \\
\text { Lu.: "I draw } \\
\text { four Indians" } \\
\text { ((while he is } \\
\text { drawing)) }\end{array}$ & $\begin{array}{l}\text { (Lu. has just } \\
\text { drawn four } \\
\text { Indians. The } \\
\text { rehabilitator } \\
\text { approves: } \\
\text { "Uhm uhm") } \\
\text { Lu.: "I write } \\
\text { twenty under } \\
\text { each one of } \\
\text { them" ((be- } \\
\text { fore writing)) }\end{array}$ & $\begin{array}{l}\text { (Lu. is reading } \\
\text { the text aloud } \\
\text { "Five ghosts } \\
\text { arrived to a } \\
\text { castle. Each } \\
\text { ghost wants to } \\
\text { buy two guns. } \\
\text { How many } \\
\text { guns do the } \\
\text { need to buy in } \\
\text { total?") } \\
\text { Lu.: "Then, } \\
\text { each one" }\end{array}$ & $\begin{array}{l}\text { (Lu. is reading } \\
\text { aloud a text in } \\
\text { which each } \\
\text { soldier has three } \\
\text { swords) } \\
\text { Lu.: "Ah, how } \\
\text { can he fight with } \\
\text { three swords?" } \\
\text { ((laughing and } \\
\text { pretending to } \\
\text { fight)) }\end{array}$ \\
\hline Explanation & $\begin{array}{l}\text { The adult is } \\
\text { suggesting } \\
\text { focusing } \\
\text { again on the } \\
\text { text informa- } \\
\text { tion, and Lu. } \\
\text { reports the } \\
\text { initial nu- } \\
\text { merical in- } \\
\text { formation } \\
\text { appearing in } \\
\text { the text }\end{array}$ & $\begin{array}{l}\text { Lu. asks for some } \\
\text { help focusing on } \\
\text { the details of his } \\
\text { drawing }\end{array}$ & $\begin{array}{l}\text { Lu.'s request for } \\
\text { confirmation gives } \\
\text { emphasis to a spe- } \\
\text { cific information }\end{array}$ & $\begin{array}{l}\text { Language } \\
\text { helps Lu. to } \\
\text { control the } \\
\text { quantity of } \\
\text { elements to } \\
\text { be included } \\
\text { in the } \\
\text { schema. }\end{array}$ & $\begin{array}{l}\text { Lu. anticipates } \\
\text { a new phase } \\
\text { of the activity }\end{array}$ & $\begin{array}{l}\text { Lu. is aware } \\
\text { that "each" is } \\
\text { an important } \\
\text { word. }\end{array}$ & \\
\hline
\end{tabular}

performing. The highest control shows in the child's talk anticipating the procedures to be adopted or the computations to be made, and in the "metacognitive" talk through which the child evaluates and/or explains what he has done or said. In the former, the child's language helps organizing actions and their sequence in the activity, in the latter the child can give emphasis to some parts of the text or redescribe actions focusing on means-ends links.

Talk only expressing emotional involvement in the activity, or only consisting of simple phrases of agreement/disagreement with what the adult says or does are coded with no analysis of cognitive control.

\section{Inter-Rater Reliability}

We computed the agreement percentage between two different raters on the coded transcriptions.

Each rater first checked the adult's talk in terms of semantic and non semantic contingency and of encoded turns and the Cohen kappa was then computed over the three codes (mutually exclusive and exhaustive) obtaining kappa = .90 (kappa was computed using the ComKappa software; see [30]). Each rater then checked the adult's talk in terms of cognitive and emotional support categories applying one of four possible codes: a) Suggestions to perform particular physical or mental actions; b) Questions, rephrasing, repetitions enabling the child to maintain the attention on the activity, or to shift the attention on a new phase of the activity; c) Building explanations and re-descriptions of the child's actions; d) Talk providing emotional support through posi- tive evaluation and encouragement. The Cohen kappa was computed over these four codes (mutually exclusive and exhaustive) obtaining kappa $=.80$.

Each rater eventually checked the child's talk applying one of seven possible codes: a) Simple answers; b) Eliciting some help or continuing utterances that have been started by the adult; c) Asking the adult to confirm the correctness of the his actions or of a previous statement; d) Describing ongoing actions; e) Anticipating procedures or computations; f) Evaluating and/or explaining actions or claims; g) Talk expressing only emotional involvement. The Cohen kappa was then computed over these seven codes (mutually exclusive and exhaustive) obtaining kappa $=.85$.

\section{RESULTS}

\section{Phase 1 and 2 Intervention (4+9 Weeks)}

"A squirrel has two bracelets on each paw. How many bracelets does the squirrel have in total?". As shown in Table 5, in which we reported the transcription of the adult-child verbal interaction, $\mathrm{Lu}$. focused on the target referent of the problem's question (i.e. the bracelets) and the adult elicited thinking about the location of such referent ("where are they?"). The representational procedure suggested by the adult was "first imagine the quantity of "holders", and then imagine the target "holdees" on them".

After one week we gave $\mathrm{Lu}$. a similar problem once again illustrated by a picture ("A female monkey has 4 earrings in each ear. How many earrings does she have?"). This time $\mathrm{Lu}$. made reference to his own body and only relied on 
Table 5. Representing the Text Situational Model in Phase 1 (March 2006)

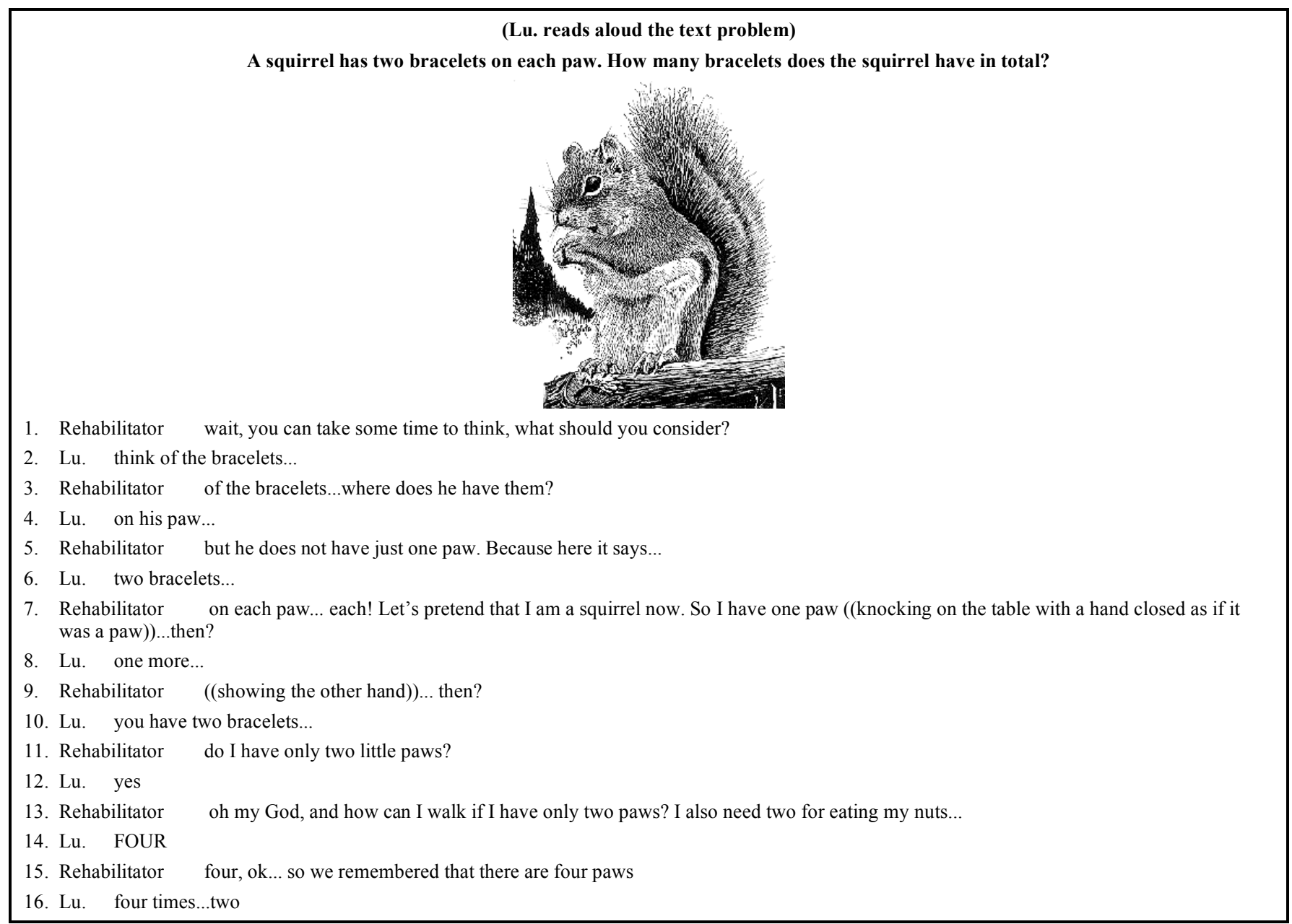

one adult's request for clarification to represent the number of the "holders".

At the beginning of phase 2 the adult told Lu. that solving problems was easier when you can deploy a schema. She read a text problem and showed Lu. that "what the text says" can be schematized in a drawing. Each step of the drawing was explained by referring to the text. In the adult's schema set A (the multiplier) was depicted through geometrical shapes and set B (the multiplicand) was represented through Arabic symbols.

The adult then asked Lu. to draw a schema for another problem that was very similar to those he was already able to represent and solve in phase 1: "Sara's cat got lots of fleas. It has 5 fleas on each leg. How many fleas does the cat have in total"? As shown in Table 6, in which we reported sequences of the adult-child verbal interaction along with the child's drawing, Lu. made a regression compared to the previous phase: he represented the text situation model with a one-toone relationship.

Considering the ten text problems that Lu. addressed during the last seven weeks of phase 2 , it is clear that his performance was quite uneven. Twice he could anticipate the computation needed to answer the problem's question with no need of drawing schemata. Four times he correctly applied the following procedure: drawing elements of set A (the multiplicand), writing the number of the "multiplier"(set B) under each element of set A; applying a repeated addition of the numbers just written down to answer the text problem question. One time he drew a simplified schema with a oneto-one relationship (similarly to the example reported in Table 6) and he once suggested that he should add everything, as he used to do in the pre-intervention phase. One important factor predicting Lu.'s incorrect performance was the sequence in which set A (the multiplier) and set B (the multiplicand) occurred in the text. When set B was presented first in the text his performance tended to be incorrect. On the contrary, when set A was presented first in the text Lu. was always correct. To understand the source of this difficulty we should remember that the procedure Lu. had learned in phase 1 intervention started with building set A "holders" and then locating set B "holdees". When the order of the numerical information in the text was consistent with the sequence of the learned procedure's components (i.e. set A first and then set B) Lu. was correct.

\section{Phase 3 Intervention (12 Weeks)}

Phase 2 of treatment was ending when the following observation was made. The text problem was "A lion tamer needs 2 whips to make his lions jump. In the cage there are 5 lions. For each lion the tamer needs 2 whips. How many whips does the tamer need in total?". After reading the text three times, Lu. said "So, for the first lion two (whips), for 
Table 6. Using a schema in Phase 2 (April 2006)

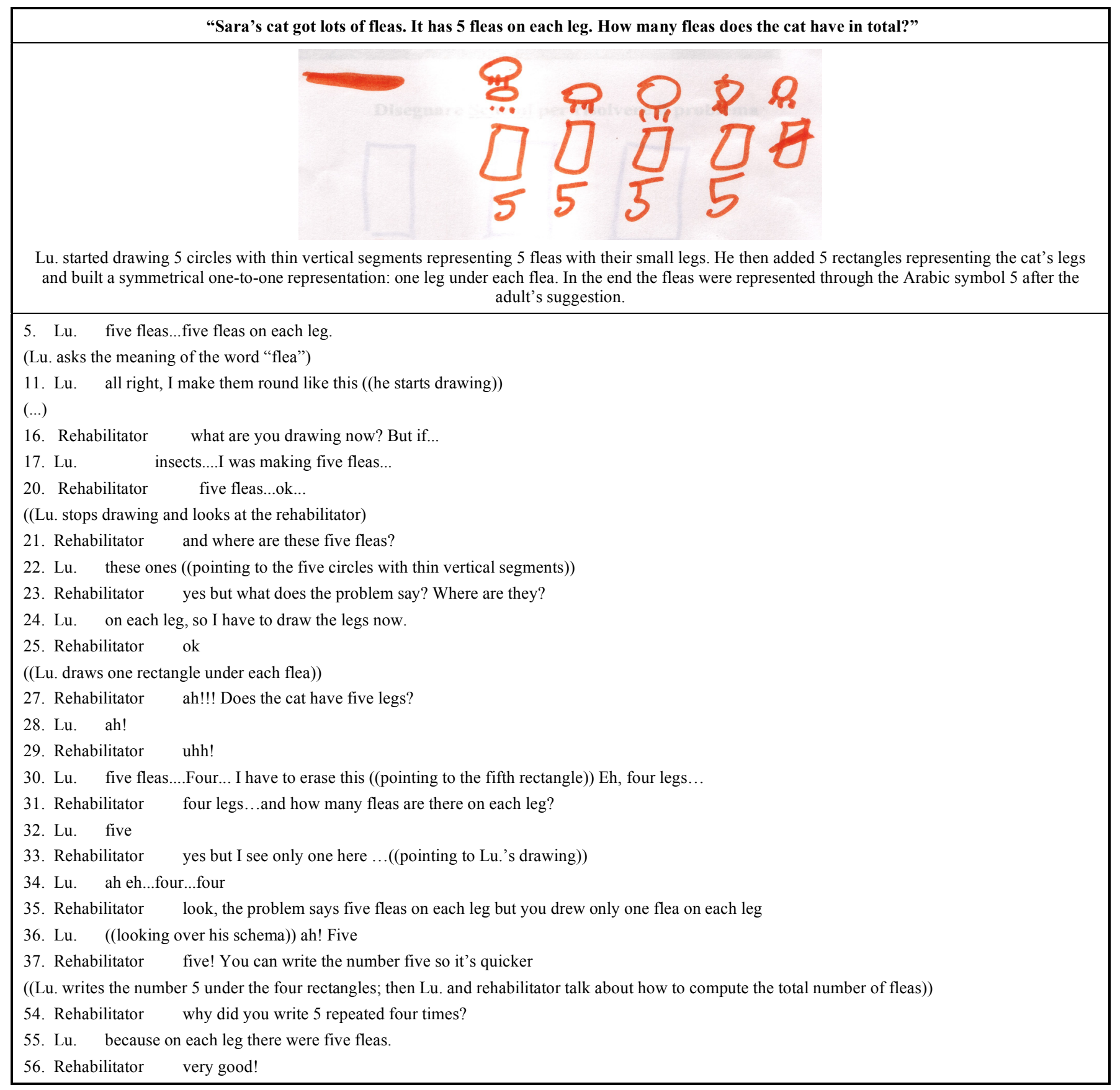

the second two, for the third two, for the fourth two, for the fifth two" and accompanied the ordinal verbal sequence showing his left hand's fingers. Then he said "I'll do it with addition" and wrote $2+2+2+2+2$.

This observation showed Lu. using a new strategy, one that nobody had taught him: transforming the numerical quantity of set $\mathrm{A}$ in an ordinal sequence, relating at the same time each element of the sequence to the numerical quantity of set B. The one-to-many relationship represented in the procedure that was co-constructed with the adult through schemata was thus explicitly analyzed by $\mathrm{Lu}$. and reconstructed through a linguistic procedure.
At the beginning of phase 3 we observed a new internal construction in Lu. (Table 7), that we referred to as "coordinating one-to-many relationships with computation". This strategy consisted in Lu. not only building an ordinal verbal sequence through which he related each element of set $A$ to the numerical quantity of set $\mathrm{B}$, but also coordinating such sequence with the computation of the total number of elements of set B.

We analyzed in Fig. (1) the fourteen text problems in which Lu. engaged during the last seven weeks of phase 3 . We can observe that Lu. had difficulties when problems required a two step solution or presented set B first. When problems mentioned set A first, the strategy of coordinating a one-to-many relationship with computation prevailed in 
Table 7. Strategies and Explanations in Phase 3

\section{November 2006}

((Lu. is reading the preface of the text problem: To find a solution need not to rush. Please read and think attentively about each sentence. To solve this problem try to imagine...))

1. Rehabilitator (Try) to imagine

((Lu. is reading the text problem: 5 ghosts arrived at a castle. Each ghost wants to buy 2 pistols. How many pistols will the ghosts buy in all?))

2. Lu. so...each

3. Rehabilitator yes

4. Lu. so, the first ghost (buys) two, the second (two) and it's four. Then the third and they are six, and the fourth.... seven and eight. And the fifth nine and ten. ((Lu. marked the sequence of ghosts with the fingers of one hand, and used the other hand's fingers to follow the pistols computation))

5. Rehabilitator very good!

6. Lu. ten pistols

7. Rehabilitator you managed to imagine and helped yourself a bit with your hands, very well!

Lu.'s performance. Even with such problems, however, on two occasions Lu. was very quick and impulsive and adopted his earlier strategy of "adding everything". He then corrected his answer either after the adult had suggested reading the text again or after noticing the key word "each" himself.

\section{Difficulties and Acquired Strategies in the Post-Test}

One month after our arithmetical text problem solving treatment had finished we engaged Lu. with four problems, explaining that we wanted to assess his learning and that, because of this, he could not ask the adult for any help. Before starting the test Lu. was given some reminders: "read the text twice if necessary, draw a schema if you feel that it is helpful, check everything in the end". Lu. had four paper sheets, each with a text problem followed by a boxed space reading "Space for writing computations, schemas and solutions".
We reported in Table $\mathbf{8}$ what Lu. wrote and drew for each problem. We can observe that problem 1 (set A first and then set B) was straightforward. Problem 2 (set B first and then set A) was very difficult to understand. First, Lu. said more than once that he could not understand it; for about four minutes he read in silence and seemed to be thinking. He then started drawing 3 circles and crossed them saying "three candies eaten each time the dog barks". He then said "I understood: Matteo ate 6 candies, and each time he ate these 6 candies, the dog barked. The first time he barked six times, the second six times, the third six times". After saying this, he drew six circles representing candies and wrote the number 6 above each of them. Thus in problem 2 the order in which the numerical information was given in the text (set B first and then set A) was transformed as if it was a "set A first" sequence. Moreover Lu. simplified the numerical information (set A and B had the same number of elements in Lu.'s solution) and computation was therefore incorrect.

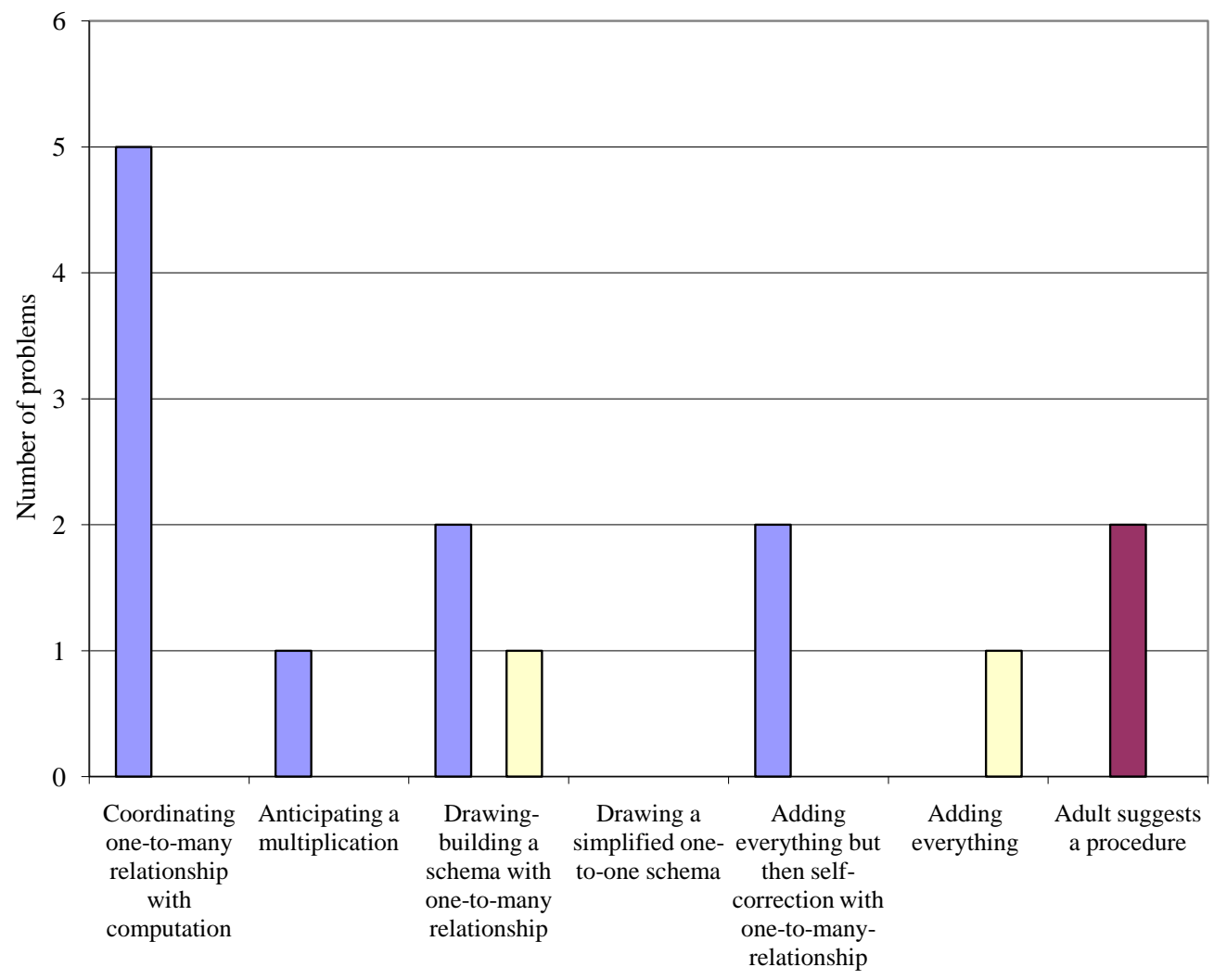

$\square$ Set A (the multiplier) first in the text problem

$\square$ Set B (the multiplicand) first in the text problem

$\square$ Problems with two steps

Fig. (1). Occurrence of different problem-solving strategies in phase 3. 
Table 8. The Post Test (14 February 2007)

\section{Problem 1 - Set A First}

Silvia bought 5 boxes of pencils. In each box there were 7 pencils. How many pencils in all did Silvia buy?

Problem 2 - Set B First

Matteo ate 3 candies each time his dog barked. Matteo's dog barked 6 times.

How many candies did Matteo eat in all?

Problem 3 - Two Steps

Federico went to the greengrocer and bought 7 apples. Each apple costs 4 euros.

He then bought 6 oranges which cost 2 euros each. How much did Federico spend at the greengrocer?

Problem 4 - Two Steps

A confectioner sold 7 trays. There were 8 cakes on each tray. Then he sold 6 trays more. There were 7 teacakes on each.

How many cakes did the confectioner sell in all?

Spazio per scrivere calcoli, schemi e soluzioni:

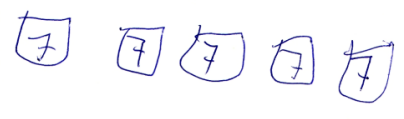

\section{$7+17+7+7=35 \quad 7 \times 5=35$}

Spazio per scrivere calcoli, schemi e soluzioni:

$\$ 2 Q$ Calmite

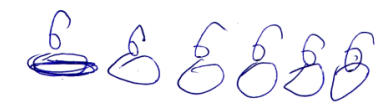

$6+6+6+6+6=31$

Spazio per scrivere calcoli, schemi e soluzioni:

$\frac{4}{2}+\frac{1}{4}+7+\frac{1}{4}+4+2+6$

0 क 30

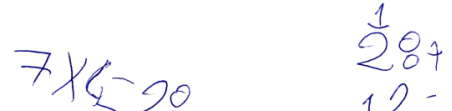

$2+2+2+2+2 \times 2 \quad 40$
$40+6$

$6+6+6+6+6+10=12$

Spazio per scrivere calcoli, schemi e soluzioni:

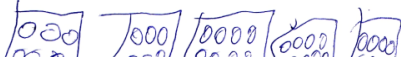

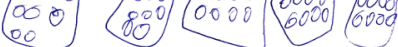

$8+8+8+8+8=1,0$

$\left[\begin{array}{l}000 \\ 0000\end{array}\right]\left[\begin{array}{l}0000 \\ 000\end{array}\right]\left[\begin{array}{l}3000 \\ 000\end{array}\right]\left[\begin{array}{l}0000 \\ 000\end{array}\right]\left[\begin{array}{l}0000 \\ 00000\end{array}\right.$

$7+7+7+7+7+6=9 \times f=2$ 
In problem 3 (two steps, set $\mathrm{A}$ first and then set $\mathrm{B}$ ) $\mathrm{Lu}$. used repetition of Arabic symbols (e.g., $7+7+7+7+7+7+7$ ) to represent the multiplier (i.e. 7 apples) and matched each symbol with another Arabic symbol representing the multiplicand (i.e. 4 euros). After computing " 28 " with repeated addition, Lu. spontaneously explained what he had written down "because each apple costs four euros and so you have to do four plus four plus four... all right I made seven plus seven as if each apple values four euros... Above each apple I wrote four euros...it means four plus four plus four plus four plus four plus four plus four (long pause) seven times four, twenty-eight". Each step of problem 4 (two steps, set A first and then set B) was correctly represented but then $\mathrm{Lu}$. forgot the final addition.

Let us now summarize the main observations emerging from this post-test. First, Lu. showed flexibility in representing a one-to-many relationship in different ways: drawing each item of set $A$ and depicting in an analogical way the numerical quantities of set B (problem 4), drawing each item of set A and matching it to an Arabic symbol representing set B (problem 1), using Arabic symbols to represent elements of both set A and B (problem 3).

Second, sensitivity to frequency of practice emerged: $\mathrm{Lu}$. performed better with the type of problem that was treated more often. Third, there was some generalisation: Lu. could solve one of the two step solution problems and could address in an effective way the other (in which he although forgot the final addition).

\section{The Adult-Child Interactive Talk}

The raw frequencies of different categories for the adult's and child's talk in all three intervention phases are shown in Tables 9 and $\mathbf{1 0 .}$

Semantically contingent turns, in which the talk continues the semantic focus of the child's previous turn, prevailed in each phase. Chi squares values of 6.5, 9.7 and 10.3 in phases 1,2 and 3 respectively were all statistically significant $(p<0.01)$ but only in phases 2 and 3 the standardized residuals showed values of 2 or greater for semantically contingent turns. This finding suggests that only after the child acquired some basic procedures (phase 2) the contingents talk significantly prevailed during the interaction.
We collapsed the adult's categories of contingent and non contingent talk in three macro-categories: suggestions to perform specific physical or mental actions, talk enhancing the child's control of attention, co-constructions of explanations and redescriptions. For each of these macro-categories, along with the emotional evaluations category, we computed the percentage of occurrence over the total number of turns of each phase. We represented these percentages in Fig. (2) below. Adult's suggestions and co-constructions of explanations decreased in phase 3, talk enhancing the child's control of attention started decreasing in phase 2. Evaluations and praises tended to increase as soon as the child's learning showed a consolidation (phase 3). Chi squares values of $16.87,11.73$ and 18.60 in phases 1,2 and 3 respectively, were all statistically significant $(\mathrm{p}<0.01)$ but only in phase 3 the standardized residuals showed values of 2 or greater for specific categories. Emotional evaluations were the most frequent type of talk used by the adult in phase 3 and this category made a statistically significant contribution to the chi square value.

Fig. (3) shows, for each treatment phase, the percentage of occurrence of four child's talk categories. Simple answers and requests for help that we regarded as "low control over the activity"- showed a clear decrease starting from phase 2 and continuing in phase 3. Anticipation of computations or procedures and metacognitive talk -that we regarded as "high control over the activity"- showed a steep increase in phase 3 . Talk only expressing emotional involvement in the activity, or consisting of simple agreement/disagreement phrases showed a decrease after phase 1 .

Chi squares values of 77.47, 39.18 and 22.32 in phases 1 , 2 and 3 respectively, were all statistically significant $(\mathrm{p}<0.01)$. In phase 1 the standardized residuals showed values of 2 or greater for the category of simple answers. In phase 2 the standardized residuals showed values of 2 or greater for the categories of both simple answers and descriptions of ongoing actions. In phase 3 the standardized residuals showed values of 2 or greater for the categories of both simple answers and anticipations of the procedures to adopt.

Thus in each phase simple answers made a statistically significant contribution to the chi square value. Starting from phase 2 , however, this contribution was paralleled by that of

Table 9. Raw Frequencies of Different Categories of the Adult's Talk in the Three Intervention

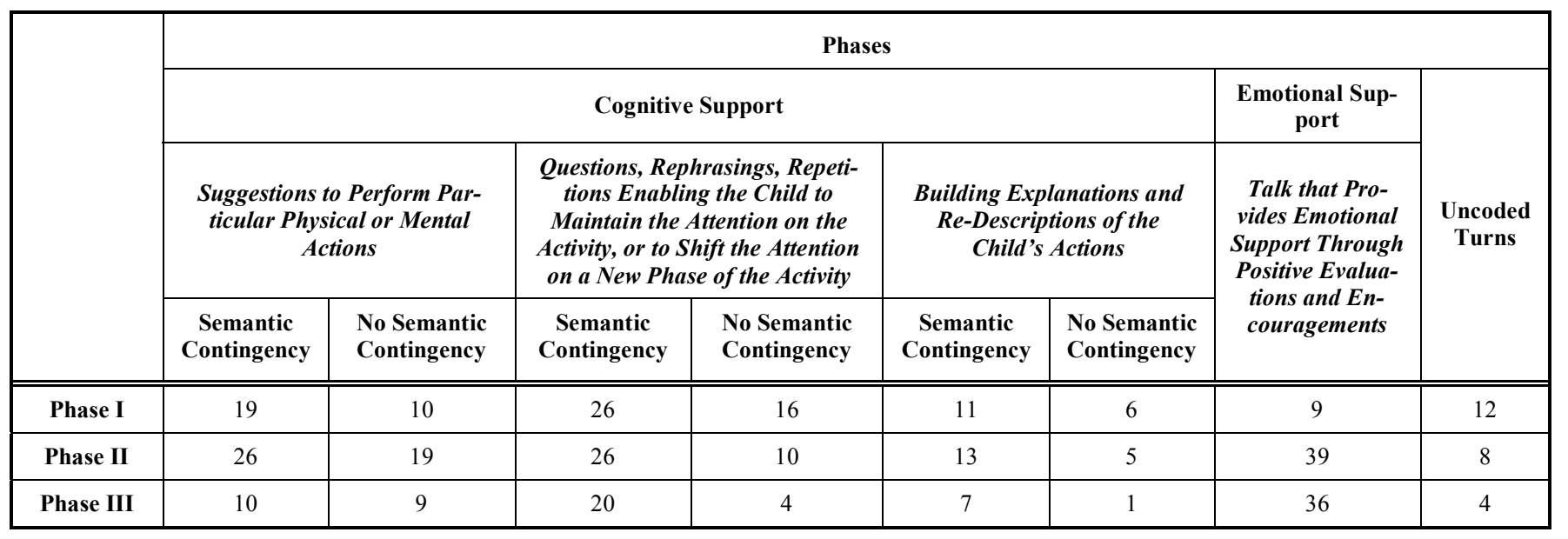


Table 10. Raw Frequencies of Different Categories of the Child's Talk in the Three Intervention Phases

\begin{tabular}{|c|c|c|c|c|c|c|c|c|}
\hline & \multicolumn{2}{|c|}{ Low Cognitive Control } & \multicolumn{2}{|c|}{ Intermediate Cognitive Control } & \multicolumn{2}{|c|}{ High Cognitive Control } & \multirow[b]{2}{*}{$\begin{array}{l}\text { Talk that } \\
\text { Only Ex- } \\
\text { presses } \\
\text { Emotional } \\
\text { Involvement }\end{array}$} & \multirow[b]{2}{*}{$\begin{array}{c}\text { Uncoded } \\
\text { Turns }\end{array}$} \\
\hline & $\begin{array}{c}\text { Simple } \\
\text { Answers }\end{array}$ & $\begin{array}{c}\text { Eliciting Some Help } \\
\text { or Continuing } \\
\text { Utterances that } \\
\text { have been Started } \\
\text { by the Adult }\end{array}$ & $\begin{array}{l}\text { Asking the Adult } \\
\text { to Confirm the } \\
\text { Correctness of the } \\
\text { Child's Actions or } \\
\text { of Previous } \\
\text { Claims }\end{array}$ & $\begin{array}{c}\text { Describing } \\
\text { Ongoing } \\
\text { Actions }\end{array}$ & $\begin{array}{l}\text { Anticipating } \\
\text { the Proce- } \\
\text { dures to } \\
\text { Adopt or the } \\
\text { Computations } \\
\text { to Make }\end{array}$ & $\begin{array}{l}\text { Evaluating } \\
\text { and/or } \\
\text { Explaining } \\
\text { Actions or } \\
\text { Claims }\end{array}$ & & \\
\hline Phase I & 35 & 6 & 2 & 1 & 16 & 4 & 11 & 15 \\
\hline Phase II & 28 & 11 & 4 & 27 & 19 & 14 & 5 & 11 \\
\hline Phase III & 16 & 3 & 7 & 13 & 17 & 11 & 5 & 4 \\
\hline
\end{tabular}

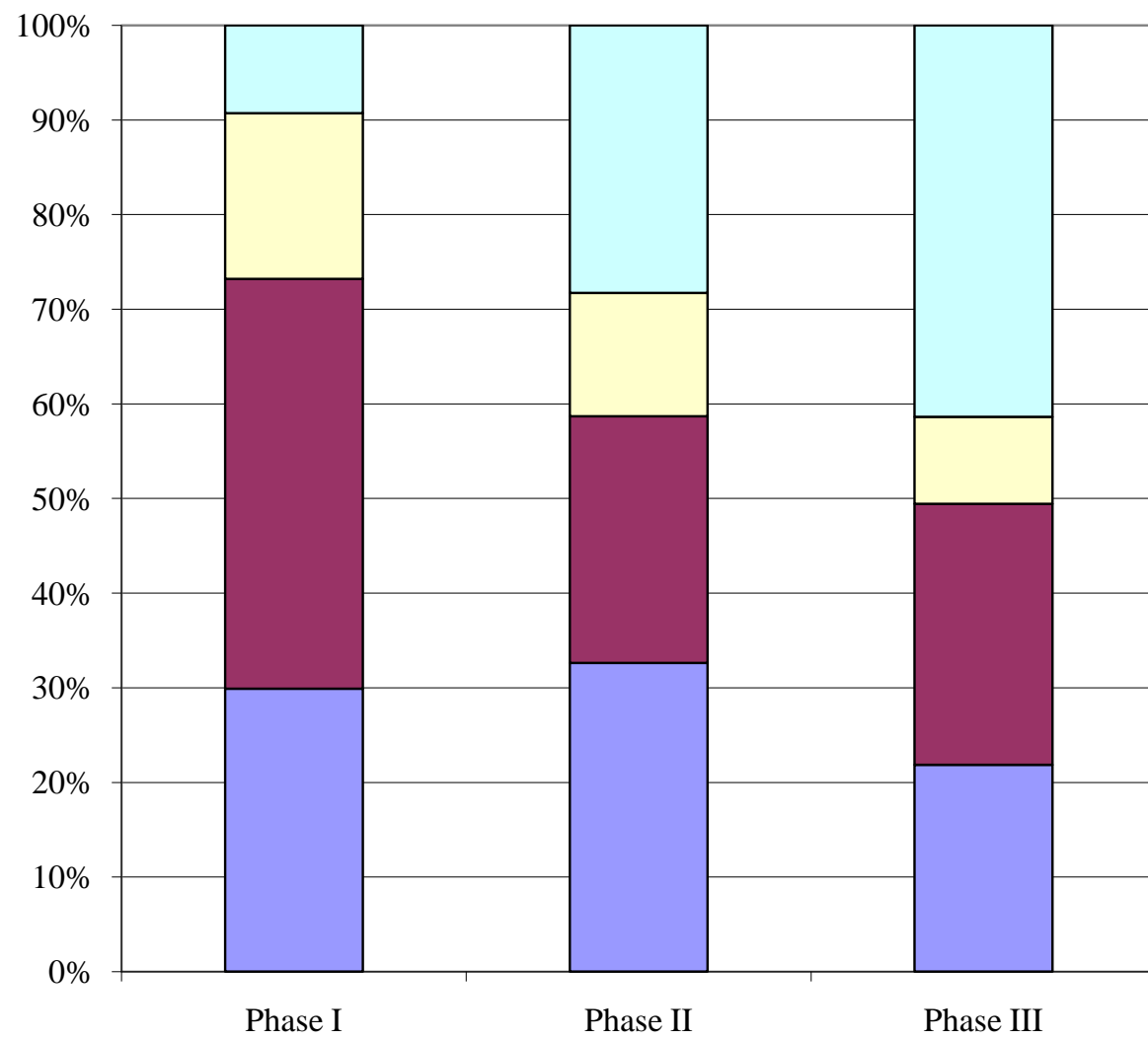

$\square$ Evaluations

$\square$ Co-constructing explanations and redescriptions

$\square$ Enhancing the child's control of attention

$\square$ Giving suggestions to perform physical or mental actions

Fig. (2). Percentage of occurrence of categories of the adult's talk.

more complex uses of language: describing and anticipating procedures or computations.

\section{CONCLUSIONS}

Our study investigated the longitudinal learning profile of Lu. -a child with intellectual disability- who was involved in cognitive rehabilitation of arithmetical text problem solving. After little training Lu. learned to represent one-to-many relationships through schemata in which he first depicted the elements of the multiplier (e.g. five squares representing 5 ships) and then matched each element with the set forming the multiplicand (e.g. the Arabic symbol 3, representing three pirates, was repeated for each ship). After some practice with schemata Lu. constructed a new procedure that we called "coordinating a one-to-many relationship with computation". In this procedure Lu. did not use schemata and built a verbal sequence in which each element of the multiplier was matched with the multiplicand and, at the same time, coordinated with repeated addition (e.g. "first ship: 3 pirates; second ship: the pirates are now 6; third ship: the pirates are now 9", and so forth). As Lu. did not receive any type of treatment for arithmetical text problem solving at home nor at school, and we did not teach him this new strategy, he spontaneously constructed the new procedure. In the last phase of intervention Lu. consolidated his procedure applying it to more abstract text problems that were never illustrated by pictures.

We identified three types of cognitive difficulties interfering with effective learning of solving arithmetical text problems. The first was keeping the specific numerical quantities of the multiplicand and the multiplier active in working memory: Lu. showed occasional interference effects using 


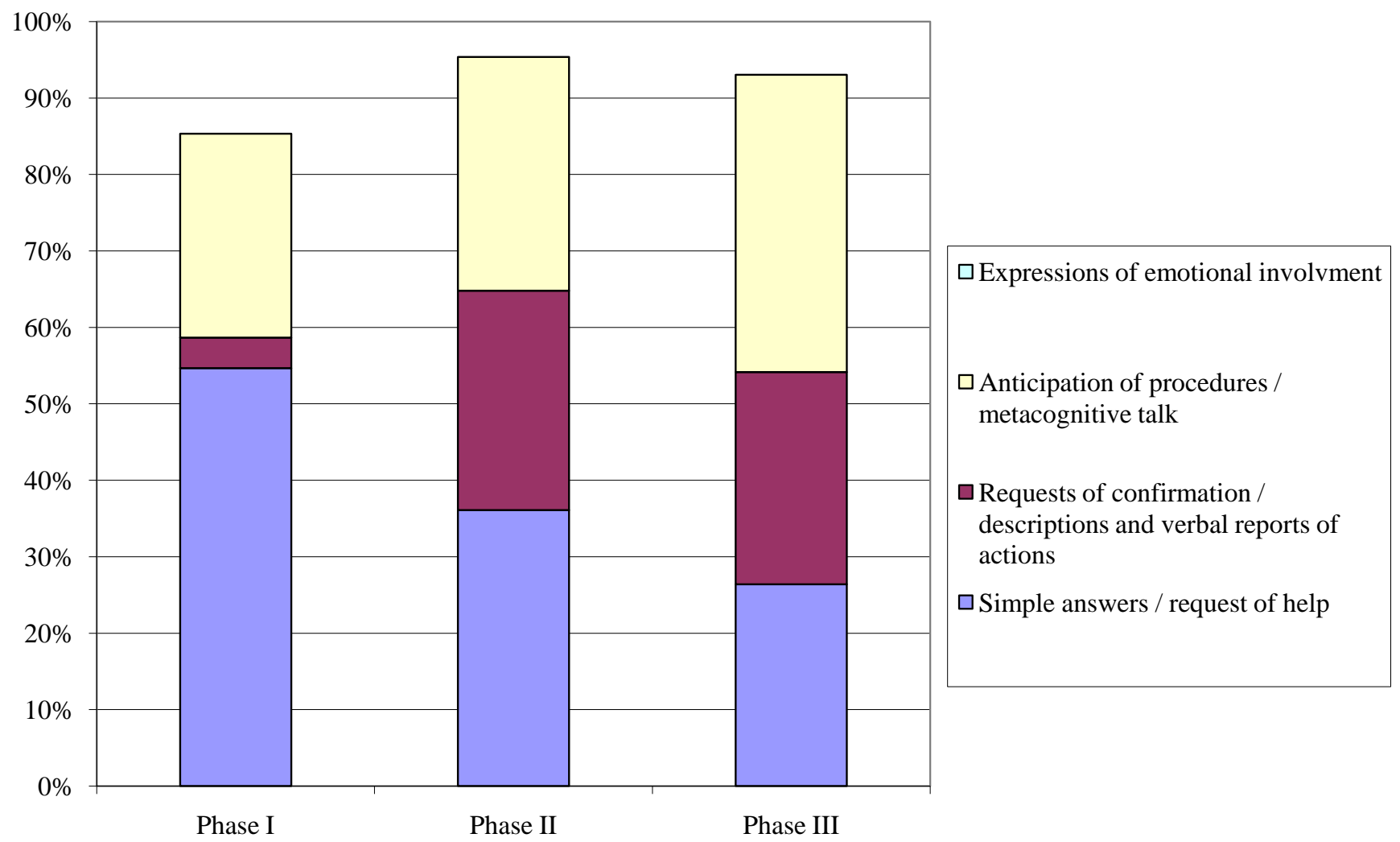

Fig. (3). Percentage of occurrence of categories of the child's talk.

the same numerical quantity for both. The second difficulty regarded the flexibility in coordinating sequential actions and sequential attention to each of the text's pieces of information. If the information sequence in the text was multiplicand first and multiplier second, Lu. tended to distort this sequence and assimilate it to the typical sequence involved in his mastered procedure (i.e. representing multiplier first and anchoring the multiplicand to it). As the coordinated control of sequential order is a highly demanding process for executive functions, we can infer that our child's difficulty stemmed from impaired executive functions.

The third difficulty was the deep slowness in learnings automatization. In the final phase of treatment there were occasional errors with the types of procedures the child had already started to apply in a rather quick and correct way. Starting being quick meant for $\mathrm{Lu}$. -however- devoting less attentional resources to the task he was attempting to accomplish. This attentional resources decrease made the performance unstable. Slow automatization of the acquired procedures that was suggested by the occasional errors occurring even in the last phase of treatment was also shown by the long time interval (i.e. 25 weeks) needed to consolidate Lu.'s learning. In summary, learning a complex activity as solving text problems with a multiplicative structure was affected by a combination of specific difficulties: sensitivity to interference effects in verbal working memory, difficulties with complex coordination of sequential actions, slow automatization. Despite such difficulties, Lu. showed the cognitive change described by Karmiloff-Smith [2] for typically developing children. A procedure that had been first learned from the adult's teaching would then be analysed in its components that were eventually verbally reconstructed by the child in a new procedure. We speculate that this cognitive change was related to two treatment conditions: the child had mastered representing the one-to-many relationship involved in multiplicative text problems graphically; the communicative acts in which the child was involved stimulated a use of language to describe actions, anticipate procedures, and explain solutions. The analysis of the adult-child interactive talk provides some empirical ground for our speculation. The child's talk changed in terms of being richer in descriptions and anticipations in computations or procedures. Through this use of language, and the practice of visual-spatial representations of multiplier-multiplicand relationship, $\mathrm{Lu}$. was provided with multiple encodings for the same procedural knowledge. Such abstract representational formats might have triggered an internal redescription and reorganization of the acquired procedures.

The observations generated from this explorative study raise two hypotheses that should be further investigated through experimental methods. First, a child with intellectual disability can learn - through interactive talk- to conceptualise the procedures acquired through some form of direct teaching. Asking to describe and explain "what we have done and why" may be a way to trigger a more abstract knowledge encoding. Second, observing that a child is able to represent and conceptualise an acquired procedure in a more explicit way may inform us on the child's "zone of proximal development" [29] and allow us to predict the child's capability of generalizing learning within the domain that has been treated ${ }^{1}$.

\footnotetext{
${ }^{1}$ Although this is anecdotical evidence, Lu. is now able to solve different types of simple problems with multiplication, division, subtraction.
} 


\section{REFERENCES}

[1] Rourke BP, van der Vlugt H, Rourke SB. Practice of child-clinical neuropsychology. Lisse, Netherlands: Swets \& Zeitlinger Publishers 2002.

[2] Karmiloff-Smith A. Beyond Modularity. Cambridge, MA: The MIT Press 1992.

[3] Nichols G, Prigogine I. Exploring Complexity: An Introduction. New York: W.H. Freeman \& Co. 1989

[4] Sohlberg M, Mateer C. Introduction to Cognitive Rehabilitation: Theory and Practice. New York: Guilford Press 1989.

[5] Gernsbacher MA. The Structure Building Framework: What it is, What it might also be, and Why. In: Britton BK, Graesser AC, Eds. Models of Understanding Text, Mahwah, New Jersey: Lawrence Erlbaum Associates Publishers 1996; pp. 89-311.

[6] Van Diik T, Kintsch W. Strategies of discourse comprehension. New York: Academy Press 1983.

[7] Kintsch W. The role of knowledge in discourse comprehension: a construction-integration model. Psychol Rev 1988; 85: 363-94.

[8] Kintsch W, Greeno JG. Understanding and solving word arithmetic problems. Psychol Rev 1985; 92: 109-29.

[9] Marshall SP. Schemas in Problem Solving. New York: Cambridge University Press 1995.

[10] Riley M, Greeno JG, Heller JI. Development of Children's Problem-Solving Ability in Arithmetic. In: Ginsburg H, Ed. The Development of Mathematical Thinking. New York: Academic Press 1983; pp. 153-96.

[11] Hudson T. Young children's difficulty with "How many more than are there?" questions. Phd [dissertation]. Diss Abstr Int 1980; 41.

[12] Bull R, Sherif G. Executive functioning as a predictor of children's mathematics ability: inhibition, switching, and working memory. Dev Psychol 2001; 19: 273-93.

[13] Geary DC, Hamson CO, Hoard MK. Numerical and arithmetical cognition: a longitudinal study of process and concept deficits in children with learning disability. J Exp Child Psychol 2000; 77: 236-63.

[14] Passolunghi MC, Cornoldi C. Working memory and cognitive abilities in children with specific difficulties in arithmetic word problem solving. Adv Learn Behav Disabil 2000; 14: 155-78.

[15] Passolunghi MC, Cornoldi C, De Liberto S. Working memory and intrusions of irrelevant information in a group of specific poor problem solvers. Mem Cognit 1999; 27: 779-90.

[16] Passolunghi MC, Marzocchi GM, Fiorillo F. Selective effect of inhibition of literal or numerical irrelevant information in children with Attention Deficit Hyperactivity Disorder (ADHD) or Arithmetic Learning Disorder (ALD). Dev Neuropsychol 2005; 28: 731-53.

[17] Fuchs LS, Fuchs D. Mathematical problem-solving profiles of students with mathematics disabilities with and without comorbid reading disabilities. J Learn Disabil 2002; 35: 563-73.

[18] Passolunghi MC, Siegel LS. Short term memory, working memory, and inhibitory control in children with specific arithmetic learning disabilities. J Exp Child Psychol 2001; 80: 44-57.

[19] Passolunghi MC, Pazzaglia F. A comparison of updating processes in children good or poor in arithmetic word problem solving. Learn Individ Differ 2005; 15: 257-69.

[20] Mazzocco M, Hagerman RJ, Cronister-Silverman A, Pennington $\mathrm{BF}$. Specific frontal lobe deficits in women with the fragile $\mathrm{X}$ gene. J Am Acad Child Adolesc Psychiatry 1992; 31: 1141-8.
[21] Mazzocco M, Pennington BF, Hagerman RJ. The neurocognitive phenotype of female's carriers of fragile X: additional evidence for specificità. J Dev Behav Pediatr 1993; 14: 328-35.

[22] Kopp CB. The Growth of Self-Monitoring Among Young Children with Down Syndrome. In: Cicchetti D, Beeghly M, Eds. Children with Down Syndrome. New York: Cambridge University Press 1990; pp. 231-51.

[23] Frith U, Frith CD. Specific motor disabilities in Down's syndrome. J Child Psychol Psychiatry 1974; 24: 293-301.

[24] Pennington BF, Bennetto L. Toward a Neuropsychology of Mental Retardation. In: Burack JA, Hodapp RM, Zigler E, Eds. Handbook of Mental Retardation and Development. New York: Cambridge University Press 1998; pp. 80-114.

[25] Jitendra A, DiPipi M, Perron-Jones N. An exploratory study of schema-based word-problem-solving instruction for middle school students with learning disabilities: an emphasis on conceptual and procedural understanding. J Spec Educ 2002; 36: 23-38.

[26] Wechsler D. WISC-R Manual for Wechsler Intelligence Scale for Children-Revised. New York: Psychological Corporation 1974 (Italian edition: Rubini V, Padovani F. WISC-R Scala di intelligenza Wechsler per bambini - Riveduta. Firenze: O.S. 1986).

[27] Campione JC, Brown AL. Linking Dynamic Assessment with School Achievement. In: Lidz CS, Ed. Dynamic Assessment: An Interactional Approach to Evaluating Learning Potential. New York: Guilford Press 1987; pp. 82-115.

[28] Haberman SJ. The analysis of residuals in cross-classified tables. Biometrics 1984; 29: 205-20.

[29] Vygotsky LS. Mind in Society: The Development of Higher Psychological Processes. Cambridge, MA: Harvard University Press 1978.

[30] Robinson BF, Bakeman R. ComKappa: a Windows 95 program for calculating kappa and related statistics. Behav Res Methods Instrum Comput 1998; 30: 731-2.

[31] Scalisi TG, Pelagaggi D, Fanini S, Romano L, Desimoni M. PACSI - Prove di Abilità Cognitive per la Scuola dell'Infanzia. Roma: Infantiae.org 2009; in press.

[32] Reynolds CR, Bigler ED. TOMAL Test of Memory and Learning. Austin, Texas: PRO-ED 1994. (Italian edition: Ianes D. TEMA Test di memoria e apprendimento. Trento: Erickson 1995).

[33] Voress JK, Pearson NA, Hammill DD. TPV Developmental Test of Visual Perception. Austin, Texas: PRO-ED 1993. (Italian edition: Ianes D. TPV Test di Percezione Visiva e Integrazione visuomotoria. Trento: Erickson 1994).

[34] Brizzolara D. Test di Vocabolario Figurato. Università di Pisa: I.R.C.C.S. "Stella Maris" 1989.

[35] Dunn LM, Dunn L. Peabody Picture Vocabulary Test. Circe Pines, MN: American Guidance Service 1981. (Italian edition: Stella G, Pizzoli C, Tressoldi PE. Peabody. Test di vocabolario recettivo. Torino: Omega Edizioni 2000).

[36] Chilosi AM, Cipriani P. Test di Comprensione Grammaticale per Bambini. Tirrenia: Edizioni del Cerro 1995.

[37] Cornoldi C, Colpo M, Gruppo MT. La Verifica Dell'Apprendimento Della Lettura. Firenze: Edizioni O.S. 1981

[38] Cornoldi C, Lucangeli D, Bellina M. Test AC-MT 6-11. In: Gruppo MT, Ed. Test di Valutazione Delle Abilità di Calcolo. Trento: Erickson 2002. 